\title{
Pathological complete response in younger and older breast cancer patients
}

Agnieszka Kołacińska1 Justyna Chałubińska², Maria Błasińska-Morawiec³, Izabela Dowgier-Witczak4, Wojciech Fendler ${ }^{5}$, Radzisław Kordek ${ }^{6}$, Zbigniew Morawiec ${ }^{1}$

1Department of Surgical Oncology, Cancer Centre, Copernicus Memorial Hospital, Lodz, Poland

2Department of Radiotherapy, Cancer Centre, Copernicus Memorial Hospital, Lodz, Poland

${ }^{3}$ Department of Proliferative Diseases, Cancer Centre, Copernicus Memorial Hospital, Lodz, Poland

4Department of Chemotherapy, Cancer Centre, Copernicus Memorial Hospital, Lodz, Poland

${ }^{5}$ Department of Paediatrics, Oncology, Haematology and Diabetology, Medical University of Lodz, Poland

${ }^{6}$ Department of Pathology, Medical University of Lodz, Poland

Submitted: 26 January 2011

Accepted: 14 April 2011

Arch Med Sci 2012; 8, 2: 310-315

DOI: $10.5114 /$ aoms.2012.28559

Copyright $\odot 2012$ Termedia \& Banach

\section{Abstract}

Introduction: Pathologic complete response (pCR) after neoadjuvant systemic treatment for inoperable locally advanced breast cancer is defined as complete microscopic disappearance of invasive cancer in both the breast and axilla in the postoperative specimen. The aim of the study was to characterize the groups of younger ( $\leq 40$ years old) and older ( $\geq 70$ years old) breast cancer patients who achieved a pCR.

Material and methods: One hundred thirty-eight consecutive patients aged between 30 and 78 years with locally advanced breast cancer, operated on after neoadjuvant systemic treatment between November 2007 and June 2010, were analyzed. In this group 9 women (6.5\%) were 40 years of age or younger, and 12 patients $(8.7 \%)$ were 70 years of age or older.

Results: In the younger group, pCR was achieved in 1 patient with triple negative, invasive ductal breast cancer, G3, BRCA 1 mutation, treated with cisplatin. A near PCR was achieved in 2 other patients, with triple negative, invasive ductal breast cancer, G3, treated with AT. The pCR in the breast was found in a HER2 positive patient. In older patients, pCR was achieved in 2 patients with triple negative, invasive ductal breast cancer, G3, treated with AT or FEC. Pathologic complete response in the axilla was achieved in 1 patient with triple negative, ductal carcinoma. The $\mathrm{pCR}$ rates were significantly higher in triple negative breast cancer in both groups ( $p=0.047$ and $p=0.018$, respectively).

Conclusions: Pathologic complete response was significantly associated with receptor- based subtypes in both young and old women.

Key words: breast cancer, pathological complete response, young, elderly.

\section{Introduction}

Pathological complete response ( $\mathrm{pCR}$ ) after neoadjuvant systemic treatment for inoperable locally advanced breast cancer with intent to change tumour status to operable or allowing reduction of its size, permitting
Corresponding author:

Agnieszka Kołacińska MD, PhD

Department

of Surgical Oncology

Copernicus Memorial Hospital

4 Paderewskiego

93-509 Lodz, Poland

Phone: +48 426895461

E-mail: info@drkolacinska.pl, agnkol@gazeta.pl 
breast conservation, is defined as complete microscopic disappearance of invasive cancer in both the breast and axilla in the postoperative specimen $[1,2]$. The sequence of neoadjuvant systemic treatment and subsequent operation provides a unique opportunity to objectively determine in vivo cancer response to preoperative chemo- or endocrine therapy $[1,3]$. The $\mathrm{pCR}$ predicts better survival, whereas a large residual cancer burden worsens diseasefree survival prognosis $[4,5]$. The age of the patient at diagnosis may influence these parameters [6-8].

The aim of our study was to characterize a group of younger ( $\leq 40$ years) and older ( $\geq 70$ years) breast cancer patients who achieved a pCR after neoadjuvant systemic treatment.

\section{Material and methods}

The Breast Cancer Database in the Departments of Chemotherapy, Proliferative Diseases and Surgical Oncology, Copernicus Memorial Hospital, Cancer Centre, Lodz, Poland was searched, and a consecutive series of 138 patients identified who had inoperable locally advanced breast cancer or resectable tumours suitable for downstaging, and treated with neoadjuvant chemo- or endocrine therapy then subsequently resected between November 2007 and June 2010.

\section{Inclusion criteria}

Breast cancer patients who had preoperative systemic therapy, 40 years of age or younger or 70 years of age or older, treated between November 2007 and June 2010, were included.

Before starting neoadjuvant systemic treatment, a diagnosis of invasive breast cancer was confirmed by core-needle biopsy of the breast tumour, although in some cases only results of fine needle aspiration with oestrogen (ER) and progesterone receptor $(P R)$ concentrations were available. Dedicated breast pathologists from the Department of Pathology, Medical University of Lodz, reviewed all biopsy specimens. The ER and PR status was determined by immunohistochemistry (IHC) using the Allred score. Human epidermal growth factor receptor 2 (HER2) status was evaluated by immunohistochemistry or by fluorescence in situ hybridization. HER2-positive tumours were defined as 3+ receptor overexpression on IHC staining and/or gene amplification found on fluorescent in situ hybridization. TNM clinical staging was assessed by mammography, ultrasound of the breast, axilla and abdomen, and chest X-ray. In selected cases, MRI of the breast was performed. The following preoperative chemo- and endocrine therapy regimens were used: AT (doxorubicin $50 \mathrm{mg} / \mathrm{m}^{2}$, docetaxel $75 \mathrm{mg} / \mathrm{m}^{2}$ ), FAC (5-fluorouracil $500 \mathrm{mg} / \mathrm{m}^{2}$, doxorubicin $50 \mathrm{mg} / \mathrm{m}^{2}$, cyclophosphamide $500 \mathrm{mg} / \mathrm{m}^{2}$ ),
FEC (5-fluorouracil $500 \mathrm{mg} / \mathrm{m}^{2}$, epirubicin $100 \mathrm{mg} / \mathrm{m}^{2}$, cyclophosphamide $500 \mathrm{mg} / \mathrm{m}^{2}$ ), AC (doxorubicin $60 \mathrm{mg} / \mathrm{m}^{2}$, cyclophosphamide $600 \mathrm{mg} / \mathrm{m}^{2}$ ), EC (epirubicin $100 \mathrm{mg} / \mathrm{m}^{2}$, cyclophosphamide $600 \mathrm{mg} / \mathrm{m}^{2}$ ), TAC (docetaxel $75 \mathrm{mg} / \mathrm{m}^{2}$, doxorubicin $50 \mathrm{mg} / \mathrm{m}^{2}$, cyclophosphamide $500 \mathrm{mg} / \mathrm{m}^{2}$ ), cisplatin (75 mg/m²), CMF (cyclophosphamide $100 \mathrm{mg} / \mathrm{m}^{2}$, methotrexate $40 \mathrm{mg} / \mathrm{m}^{2}, 5$-fluorouracil $600 \mathrm{mg} / \mathrm{m}^{2}$ ), and anastrozole. The various regimens were in 21-day cycles, except for 28-day CMF cycles. Anastrozole was taken orally $1 \mathrm{mg}$ daily. Upon completion of chemotherapy (4-6 cycles), dedicated breast surgeons performed mastectomy or breast conservation, with axillary dissection or sentinel node biopsy. Postoperative specimens were examined by dedicated breast pathologists. pCR was defined as postoperative microscopic absence of invasive carcinoma in breast tissue, and axillary lymph nodes after neoadjuvant systemic treatment. A near complete response with only minimal residual disease was described as scattered tumour cells in the primary tumour site or lymph node or minimal cellularity in the surgical specimen. PCR and near PCR were key points in statistical analysis.

As these procedures were routine diagnosis and treatment; ethical approval and informed consent were not required.

\section{Statistical analysis}

The computer package Statistica version 8.0 (StatSoft) was used for all statistical analyses. The two-tailed Fisher's exact test was used to compare variables with a $p$ value of 0.05 established as the threshold of statistical significance.

\section{Results}

\section{Young age group}

Of 138 consecutive patients from our database, 9 women (6.5\%) were between 30 and 40 years old, mean age 36.3 years, all with invasive ductal breast cancer; grade $\mathrm{G} 2-2$ patients, $\mathrm{G} 3-6$ patients, $\mathrm{Gx}$ - 1 patient; stage IIB - 1 patient, IIIA - 5 patients, IIIB - 2 patients, IIIC -1 patient; ER(0)PR(0)HER2(0) (triple negative) -4 patients, ER(+)PR(+)HER2(0) 2 patients, $\mathrm{ER}(+) \mathrm{PR}(+) \mathrm{HER} 2(+)-2$ patients, ER(0)PR(0)HER2(+) - 1 patient. Neoadjuvant regimens comprised: AT -6 patients, TAC -1 patient, AC - 1 patient, cisplatin - 1 patient. After completion of neoadjuvant chemotherapy, mastectomy was performed in 8 patients, and breast conservation in 1 patient. The pCR was achieved in 1 patient from this younger patient group (1/9, fraction $=0.11$, with triple negative, invasive ductal breast cancer, G3, BRCA1 mutation, treated with cisplatin. Furthermore, a near complete response to preoperative chemotherapy was achieved in 2 other patients. These also had triple negative, 
invasive ductal breast cancers, G3, treated with AT. One of these had a pCR in the axilla but scattered $2 \mathrm{~mm}$ cancer cells in the breast, in the mastectomy specimen. In the other, pCR was achieved in the breast but a $3 \mathrm{~mm}$ metastasis remained in the axillary lymph node after breast conservation. Additionally, $P C R$ in the breast was found in a HER2 positive breast cancer patient, treated with AT. The characteristics of these young ( $\leq 40$ years old) patients are shown in Table IA and II. Comparison of pCR according to receptor-based subtypes and grade with $p$ values is summarized in Table III.

\section{Older age group}

Of 138 consecutive patients from our database, 12 (8.7\%) were between 70 and 78 years old, mean age 72.3. Histopathological tumour type: invasive ductal carcinoma (9 patients), invasive lobular classical type (1 patient), invasive lobular pleomorphic type mixed with $5 \%$ invasive ductal cancer (1 patient), mucinous cancer (1 patient). Tumour grade: there were 1,3 and 8 patients with grades Gx, G2 and G3, respectively. Tumour staging: stage IIA (1 patient), IIIA (4 patients), IIIB (6 patients), IIIC (1 patient). Receptors: ER(+)PR(+)HER2(0) in 4 patients, ER(0)PR(0)HER2(0) (triple negative) in 4 patients, ER(0)PR(+)HER2(0) in 1 patient, ER(+)PR(+)HER2-ambiguous in 1 patient, ER(0)PR(0)
HER2(+) in 1 patient, ER(+)PR(0)HER2(+) in 1 patient The following neoadjuvant chemotherapy regimens were used: AT -4 patients, FEC -4 patients, FAC - 1 patient, CMF - 1 patient, EC - 1 patient; in 1 patient neoadjuvant endocrine therapy (anastrozole) was used. After completion of systemic therapy, mastectomy with axillary dissection was performed in all patients. pCR was achieved by AT or $\mathrm{FEC}$ in 2 patients $(2 / 12$; fraction $=0.16)$ with triple negative, invasive $\mathrm{G} 3$ ductal cancer. Additionally, pCR in the axilla was achieved with neoadjuvant FAC in 1 other patient with triple negative, G3 invasive ductal cancer. Characteristics of the older $(\geq 70$ years old) breast cancer patient group are shown in Table I B and II. Comparison of pCR according to receptor-based subtypes, grade and histopathological tumour type with $p$ values is summarized in Table III.

In both young and old groups, higher rates of pCR were observed in patients with triple negative receptor status ( $p=0.047$ and $p=0.018$, respectively; Table III). No statistical differences were found in terms of ER, PR, or HER2 receptor status in both groups (Table III). The tumour grade showed no statistically significant influence on $\mathrm{pCR}$ both in young and old patients ( $p=0.46$ and $p=0.49$ ). In women aged 70 years and above, no differences in $P C R$ were shown in terms of histopathological cancer type $(p=0.5$; Table III).

Table I A. Pathological response after neoadjuvant chemotherapy in younger breast cancer patients ( $\leq 40$ years old)

\begin{tabular}{|c|c|c|c|c|c|c|c|c|c|c|c|c|}
\hline Patient & $\begin{array}{c}\text { Age } \\
\text { [years] }\end{array}$ & $\begin{array}{c}\text { Cancer } \\
\text { type }\end{array}$ & ER & PR & HER2 & G & cTN & урTN & CHT & Surgery & $\begin{array}{r}\text { BRCA } \\
\text { mutatio }\end{array}$ & $\mathrm{pCR}$ \\
\hline 1 & 30 & Inv ductal & 0 & 0 & + & G3 & CT4N3 & ypT2N3 & TAC & Mastectomy & No & No \\
\hline 2 & 35 & Inv ductal & 0 & 0 & 0 & G3 & cT4N2 & $\begin{array}{c}\text { ypT1aNo } \\
\text { (scattered } \\
2 \text { mm cancer } \\
\text { cells in breast) }\end{array}$ & AT & Mastectomy & No & $\begin{array}{l}\text { Very good } \\
\text { response } \\
\text { (near pCR) }\end{array}$ \\
\hline 3 & 35 & Inv ductal & + & + & 0 & G3 & $\mathrm{CT} 2 \mathrm{~N} 2$ & урT1cN1 & $A C$ & Mastectomy & No & No \\
\hline 4 & 36 & Inv ductal & + & + & + & $G x$ & cT2N2 & ypT1cN2a & AT & Mastectomy & No & No \\
\hline 5 & 36 & Inv ductal & + & + & 0 & $\mathrm{G} 2$ & cT3N2 & урT1cN1a & AT & Mastectomy & No & No \\
\hline 6 & 37 & Inv ductal & 0 & 0 & 0 & G3 & $\mathrm{cT} 2 \mathrm{~N} 2$ & ypTONO & $\begin{array}{l}\text { Cis- } \\
\text { platin }\end{array}$ & Mastectomy & Yes & $\mathrm{pCR}$ \\
\hline 7 & 39 & Inv ductal & + & + & + & $\mathrm{G} 2$ & cT3N2 & ypTON2 & AT & Mastectomy & No & pCR in breast \\
\hline 8 & 39 & Inv ductal & 0 & 0 & 0 & G3 & $\mathrm{cT} 2 \mathrm{~N} 1$ & $\begin{array}{c}\text { ypToN1 } \\
\text { (scattered } \\
3 \text { mm cancer } \\
\text { cells in one } \\
\text { axillary node) }\end{array}$ & AT & $\mathrm{BCT}$ & No & $\begin{array}{l}\text { Very good } \\
\text { response } \\
\text { (near pCR) }\end{array}$ \\
\hline 9 & 40 & Inv ductal & 0 & 0 & 0 & G3 & cT4NO & $\begin{array}{l}\text { ypT4bN1 } \\
\text { (3 months } \\
\text { later lung } \\
\text { metastases }\end{array}$ & AT & Mastectomy & No & Progression \\
\hline
\end{tabular}

Inv ductal - invasive ductal, G - grading, CTN - clinical staging (tumour and nodes), ypTN-pathological staging (tumour and nodes), $C H T$ - chemotherapy, BCT - breast conserving therapy, $p C R$ - pathological complete response 
Table I B. Pathological response after neoadjuvant chemo- and endocrine therapy in older breast cancer patients $(\geq 70$ years old $)$

\begin{tabular}{|c|c|c|c|c|c|c|c|c|c|c|c|}
\hline & $\begin{array}{c}\text { Age } \\
\text { [years] }\end{array}$ & $\begin{array}{c}\text { Cancer } \\
\text { type }\end{array}$ & ER & PR & HER2 & G & cTN & ypTN & $\mathrm{CHT}$ & Surgery & $\mathrm{pCR}$ \\
\hline P1 & 70 & Inv ductal & + & + & 0 & $\mathrm{G} 2$ & cT4N2 & урT2mN1 & AT & Mastectomy & No \\
\hline P2 & 70 & Inv ductal & + & + & $a m b$ & $G x$ & CT4N1 & ypT2N3 & FEC & Mastectomy & No \\
\hline P3 & 70 & Inv ductal & 0 & 0 & 0 & G3 & CT4N1 & ypT2NO & FAC & Mastectomy & $\mathrm{pCR}$ in axilla \\
\hline P4 & 70 & Inv ductal & + & + & 0 & $\mathrm{G} 2$ & CT3N1 & урT2N1 & AT & Mastectomy & No \\
\hline P5 & 71 & Inv ductal & 0 & 0 & 0 & G3 & CT3N1 & ypTONO & FEC & Mastectomy & $p C R$ \\
\hline P6 & 71 & Inv ductal & 0 & 0 & 0 & G3 & CT2NO & ypT2N1 & CMF & Mastectomy & Progression \\
\hline P7 & 71 & Inv ductal & 0 & 0 & 0 & G3 & cT4N1 & урTONO & AT & Mastectomy & $\mathrm{pCR}$ \\
\hline P8 & 73 & Inv lobular & + & + & 0 & G3 & cT4N2 & ypT3N3 & AT & Mastectomy & No \\
\hline P9 & 73 & Inv ductal & + & + & 0 & $\mathrm{G} 2$ & CT3N1 & ypT2N1 & EC & Mastectomy & No \\
\hline P10 & 74 & $\begin{array}{c}\text { Pleom. } \\
\text { lobular } 95 \% \text {, } \\
\text { inv ductal } 5 \%\end{array}$ & 0 & 0 & + & G3 & CT4N2 & ypT3N2 & FEC & Mastectomy & No \\
\hline P11 & 77 & Inv ductal & 0 & + & 0 & G3 & cT3N2 & ypT1N2b & Anastrozole & Mastectomy & No \\
\hline $\mathrm{P} 12$ & 78 & Mucinous & + & 0 & + & G3 & CT2N3 & ypT2N2 & FEC & Mastectomy & No \\
\hline
\end{tabular}

Inv ductal - invasive ductal, Inv lobular - invasive lobular, Pleom. lobular - pleomorphic lobular, amb - ambiguous, G - grading, cTN - clinical staging (tumour and nodes), ypTN-pathological staging (tumour and nodes), CHT-chemotherapy, $p C R$ - pathological complete response

\section{Discussion}

Scientific studies have shown that age of breast cancer patients is inversely related to tumour aggressiveness and outcome [6-9]. Both age groups younger than 40 years and older than 70 years are outside the upper and lower age limits in screening programmes in the majority of countries in the world [9]. We have therefore focused attention on patients in both of these age groups, and in particular with respect to pathological remission after neoadjuvant systemic treatment. Several articles have shown that the highest rate of pCR occurs in triple negative and HER2 positive breast cancer subtypes in comparison with $\mathrm{ER}(+)$ tumours, but no age stratification has been demonstrated [10-13]. Consistently, in our study pCR or a near complete pathological response to neoadjuvant chemotherapy was achieved in the younger cohort of patients in triple negative breast cancer, which was statistically significant $(p=0.047)$, and $p C R$ solely in the breast in an HER2 positive tumour. Similarly, in the older age group ( $\geq 70$ years old) we observed $P C R$ and $\mathrm{PCR}$ in the axilla in the triple negative breast cancer subtype ( $p=0.018)$. Indeed, surgeons from the Netherlands Cancer Institute have stated that among various variables such as menopausal status, tumour stage, nodal involvement, and histology, the receptor-based subtype was the only significant predictor of $\mathrm{pCR}$, with triple negative patients being more chemosensitive [10]. Recently a new surrogate, the residual cancer burden (RCB), has been proposed to measure chemosensitivity as a continuous variable derived from the primary
Table II. Summary characteristics of the two study groups

\begin{tabular}{|lcc|}
\hline Parameter & $\leq 40$ years & $\geq 70$ years \\
\hline Age (mean \pm SD) & $36.3 \pm 3.0$ & $72.3 \pm 2.8$ \\
\hline $\begin{array}{l}\text { Cancer type } \\
\text { (ductal/other types) }\end{array}$ & $9 / 0$ & $9 / 3$ \\
\hline ER (positive/negative) & $4 / 5$ & $6 / 6$ \\
\hline PR (positive/negative) & $4 / 5$ & $6 / 6$ \\
\hline HER2 (positive/negative) & $3 / 9$ & $3 / 9$ \\
\hline $\begin{array}{l}\text { Triple negative vs. ER, PR } \\
\text { and/or HER2 positive }\end{array}$ & $4 / 5$ & $4 / 8$ \\
\hline G (G3/G2 or Gx) & $6 / 3$ & $8 / 4$ \\
\hline pCR/no pCR & $3 / 6$ & $3 / 9$ \\
\hline
\end{tabular}

tumour dimensions, cellularity of the tumour bed, and axillary nodal burden. The RCB is a significant predictor of distant relapse-free survival and can be used to more precisely determine the response to chemotherapy [11]. Peintinger et al. have stated that minimal residual disease (RCB-I) carries comparable prognosis as pCR (RCB-0) [5]. In contrast, extensive residual disease (RCB-III) is associated with poor prognosis [5, 10-12]. In view of the small sample size, in our study $P C R$ and near $P C R$ were combined in the statistical analysis. This can be justified in the light of research conducted by pathologists, surgical oncologists, medical oncologists and biologists from the University of Texas M.D. Anderson Cancer Center and Vall d'Hebron University Hospital, Barcelona [5, 10-12]. 
Table III. Comparison of pCR according to receptor subtypes, tumour grade and histopathological type in younger and older breast cancer patients (Fisher's 2-tailed exact test)

\begin{tabular}{|c|c|c|c|c|}
\hline $\begin{array}{l}\text { pCR according } \\
\text { to receptor subtype }\end{array}$ & $\begin{array}{c}\text { pCR/no pCR } \\
\text { (in women aged } \\
40 \text { years and below) }\end{array}$ & $\begin{array}{c}\text { Value of } p \text { in women } \\
\text { aged } 40 \text { years } \\
\text { and below }\end{array}$ & $\begin{array}{c}\text { PCR/no pCR } \\
\text { (in women aged } \\
70 \text { years and above) }\end{array}$ & $\begin{array}{c}\text { Value of } p \text { in women } \\
\text { aged } 70 \text { years } \\
\text { and above }\end{array}$ \\
\hline $\mathrm{ER}(-)$ vs. $\mathrm{ER}(+)$ & $3 / 2$ vs. $0 / 4$ & 0.16 & $3 / 3$ vs. $0 / 6$ & 0.18 \\
\hline $\mathrm{PR}(-)$ vs. $\mathrm{PR}(+)$ & $3 / 2$ vs. $0 / 4$ & 0.16 & $3 / 3$ vs. $0 / 6$ & 0.18 \\
\hline HER2(-) vs. HER2(+) & $3 / 3$ vs. $0 / 3$ & 0.46 & $3 / 6$ vs. $0 / 3$ & 0.51 \\
\hline $\begin{array}{l}\text { ER(-)PR(-) HER2(-) } \\
\text { triple negative vs. } \\
\text { other subtypes }\end{array}$ & $3 / 1$ vs. $0 / 5$ & 0.047 & $3 / 1$ vs. $0 / 8$ & 0.018 \\
\hline $\begin{array}{l}\mathrm{pCR} \text { according } \\
\text { to grade }\end{array}$ & $\begin{array}{c}\text { pCR vs. no pCR } \\
\text { (in women aged } \\
40 \text { years and below) }\end{array}$ & $\begin{array}{c}\text { Value of } p \text { in women } \\
\text { aged } 40 \text { years } \\
\text { and below }\end{array}$ & $\begin{array}{c}\text { pCR vs. no pCR } \\
\text { (in women aged } \\
70 \text { years and above) }\end{array}$ & $\begin{array}{c}\text { Value of } p \text { in women } \\
\text { aged } 70 \text { years } \\
\text { and above }\end{array}$ \\
\hline G3 vs. G2, Gx & $3 / 3$ vs. $0 / 3$ & 0.46 & $3 / 5$ vs. $0 / 4$ & 0.49 \\
\hline \multicolumn{2}{|l|}{$\begin{array}{l}\text { pCR according to } \\
\text { histopathological type }\end{array}$} & $\begin{array}{l}\text { vs. no pCR (in women } \\
70 \text { years and above) }\end{array}$ & \multicolumn{2}{|c|}{$\begin{array}{l}\text { Value of } p \text { in women aged } \\
70 \text { years and above }\end{array}$} \\
\hline \multicolumn{2}{|c|}{$\begin{array}{l}\text { Invasive ductal vs. other types } \\
\text { (lobular, mixed, mucinous) }\end{array}$} & $3 / 6$ vs. $0 / 3$ & \multicolumn{2}{|r|}{0.5} \\
\hline
\end{tabular}

With respect to histological subtypes, it has previously been demonstrated that the $\mathrm{PCR}$ rate after primary chemotherapy is significantly lower in invasive lobular carcinoma, frequently characterized by high expression of steroid hormone receptors, when compared with the invasive ductal histotype $[3,13]$. In our cohort of patients, both younger ( $\leq 40$ years old) and older ( $\geq 70$ years old), pCR in the breast and/or in the axilla was achieved in patients with invasive ductal breast cancer, which is in accordance with the literature [3].

Measures of high cell proliferation such as high grade also correlate with good response to neoadjuvant chemotherapy $[14,15]$. In our study, all younger and older patients who achieved pCR or good partial response had G3 tumours. Our previous research on the characteristics of 101 breast cancer patients across the complete age range (30-78 years, median: 56.1 years), treated in our institution, also showed the highest rate of pCR in triple negative breast cancer patients, G3, with invasive ductal carcinoma [16]. These results mirror the characteristics of younger ( $\leq 40$ years old) and older ( $\geq 70$ years old) age groups in the present article. Although published breast cancer models stratified by age have shown disparities between younger and older women, with more favourable tumour biology in the latter [6, 7], the association of receptor-based subtypes (triple negative) with PCR rates was comparable in both age groups in our study. However, in view of the small sample size, we plan to study a more extensive cohort with special emphasis on the impact of pCR on survival in young and elderly patients. This is particularly important because, despite the highest rate of $p C R$ in triple negative and HER2 positive tumours, those with residual disease after neoadjuvant systemic treatment carry the worst overall survival, with a high relapse rate $[17,18]$. One of the studied patients from the younger group, aged 40 years, with triple negative breast cancer, with a large residual tumour burden after completion of chemotherapy (AT) and mastectomy, developed massive lung metastases 3 months later (Table I). In view of this observation, it is vital to differentiate triple negative breast cancer patients with defective DNA repair similar to BRCA1-associated tumours that are sensitive to anthracyclines and resistant to taxanebased chemotherapy [19, 20].

In conclusion, we have concluded that PCR was significantly linked to receptor-based subtype in both young ( $\leq 40$ years) and old ( $\geq 70$ years) women. pCR rates were statistically significantly higher in triple negative breast cancer in both groups. Further studies are needed to incorporate multigene signatures within the receptor-based classification to predict chemosensitivity in the adjuvant setting [21] and to design targeted therapies in the genomic and proteomic era [22-24].

\section{References}

1. Bhargava R, Beriwal S, Dabbs DJ, et al. Immunohistochemical surrogate markers of breast cancer molecular classes predicts response to neoadjuvant chemotherapy. Cancer 2010; 116: 1431-9.

2. Bernsdorf $M$, Ingvar C, Jorgensen L, et al. Effect of adding gefitinib to neoadjuvant chemotherapy in estrogen receptor negative early breast cancer in randomized phase II trial. Breast Cancer Res Treat 2011 Jan 15 [Epub ahead of print].

3. Tubiana-Hulin M, Stevens D, Lasry S, et al. Response to neoadjuvant chemotherapy in lobular and ductal breast 
carcinomas: a retrospective study on 860 patients from one institution. Ann Onc 2006; 17: 1228-33.

4. Adams S, Chakravarthy AB, Donach $M$, et al. Preoperative concurrent paclitaxel- radiation in locally advanced breast cancer: pathologic response correlates with 5-year overall survival. Breast Cancer Res Treat 2010; 124: 723-32.

5. Peintinger F, Buzdar AU, Kuerer HM, et al. Hormone receptor status and pathologic response of HER2-positive breast cancer treated with neoadjuvant chemotherapy and trastuzumab. Ann Oncol 2008; 19: 2020-5.

6. Bharat A, Aft RL, Gao F, et al. Patient and tumor characteristics associated with increased mortality in young women ( $<$ or $=40$ years) with breast cancer. J Surg Oncol 2009; 100: 248-51.

7. Gnerlich JL, Deshpande AD, Jeffe DB, et al. Elevated breast cancer mortality in women younger than age 40 years compared with older women is attributed to poorer survival in early- stage disease. J Am Coll Surg 2009; 208: 341-7.

8. Cyr A, Gillanders WE, Aft RL, et al. Breast cancer in elderly women ( $\geq 80$ years): variation is standard of care? J Surg Oncol 2010 Nov 23 [Epub ahead of print].

9. Szekely B, Madaras L, Szentmartoni G, et al. Comparison of breast cancer in young and old women based on clinicopathological features. Magy Onkol 2010; 54: 19-26.

10. Straver ME, Rutgers EJ, Rodenhuis S, et al. The relevance of breast cancer subtypes in the outcome of neoadjuvant chemotherapy. Ann Surg Oncol 2010; 17: 2411-8.

11. Symmans WF, Peintinger F, Hatzis C, et al. Measurement of residual breast cancer burden to predict survival after neoadjuvant chemotherapy. J Clin Oncol 2007; 25: 4414-22.

12. Mittendorf EA, Wu Y, Scaltriti $M$, et al. Loss of HER2 amplification following trastuzumab-based neoadjuvant systemic therapy and survival outcomes. Clin Cancer Res 2009; 15: 7381-8

13. Colleoni M, Viale G, Goldhirsch A. Lessons on responsiveness to adjuvant systemic therapies learned from the neoadjuvant setting. Breast 2009; 18 (Suppl 3): S137-40.

14. Colleoni M, Bagnardi V, Rotmensz N, et al. A nomogram based on the expression of $\mathrm{Ki}-67$, steroid hormone receptor status and number of chemotherapy courses to predict pathological complete remission after preoperative chemotherapy for breast cancer. Eur J Cancer 2010; 46: 2216-24.

15. Tan MC, Al Mushawah F, Gao F, et al. Predictors of complete pathological response after neoadjuvant systemic therapy for breast cancer. Am J Surg 2009; 198: 520-5.

16. Kolacinska A, Blasinska-Morawiec M, Dowgier-Witczak I, Kordek R, Morawiec Z. Characteristics of breast cancer patients with pathological complete response after neoadjuvant chemotherapy. Przegl Menopau 2010; 5: 300-4.

17. Keam B, Im SA, Kim HJ, et al. Prognostic impact of clinicopathologic parameters in stage II/III breast cancer treated with neoadjuvant docetaxel and doxorubicin chemotherapy: paradoxical features of the triple negative breast cancer. BMC Cancer 2007; 7: 203-13.

18. Isakoff SJ. Triple-negative breast cancer. Role of specific chemotherapy agents. Cancer J 2010; 16: 53-61.

19. Byrski T, Gronwald J, Huzarski T, et al. Pathologic complete response in young women with BRCA1-positive breast cancers after neoadjuvant chemotherapy. J Clin Oncol 2010; 28: 361-3.

20. Rodriguez AA, Makris A, Wu MF, et al. DNA repair signature is associated with anthracycline response in triple negative breast cancer patients. Breast Cancer Res Treat 2010; 123: 189-96.

21. Straver ME, Glas AM, Hannemann J, et al. The 70-gene signature as a response predictor for neoadjuvant chemotherapy in breast cancer. Breast Cancer Res Treat 2010; 119: 551-8.

22. Yiu CC, Sasano H, Ono K, Chow LW. Changes in protein expression after neoadjuvant use of aromatase inhibitors in primary breast cancer: a proteomic approach to search for potential biomarkers to predict response or resistance. Expert Opin Investig Drugs 2010; Suppl 1: S79-89.

23. Yildiz Y, Yayllm-Eraltanl I, Arikan S, et al. Is there any correlation between TNF-related apoptosis-inducing ligand (TRAIL) genetic variants and breast cancer? Arch Med Sci 2010; 6: 932-6.

24. Dunn L, Demichele A. Genomic predictors of outcome and treatment response in breast cancer. Mol Diagn Ther 2009; 13: 73-90. 